University of Nebraska - Lincoln

DigitalCommons@University of Nebraska - Lincoln

1987

\title{
A Preliminary Investigation of a Relationship between South American Snow Cover and the Southern Oscillation
}

\author{
Randall S. Cerveny \\ Arizona State University \\ Brent R. Skeeter \\ University of Nebraska - Lincoln \\ Kenneth F. Dewey \\ University of Nebraska - Lincoln, kdewey@unl.edu
}

Follow this and additional works at: https://digitalcommons.unl.edu/natrespapers

Part of the Natural Resources and Conservation Commons, Natural Resources Management and Policy Commons, and the Other Environmental Sciences Commons

Cerveny, Randall S.; Skeeter, Brent R.; and Dewey, Kenneth F., "A Preliminary Investigation of a Relationship between South American Snow Cover and the Southern Oscillation" (1987). Papers in Natural Resources. 1083.

https://digitalcommons.unl.edu/natrespapers/1083

This Article is brought to you for free and open access by the Natural Resources, School of at DigitalCommons@University of Nebraska - Lincoln. It has been accepted for inclusion in Papers in Natural Resources by an authorized administrator of DigitalCommons@University of Nebraska - Lincoln. 


\title{
NOTES AND CORRESPONDENCE
}

\section{A Preliminary Investigation of a Relationship between South American Snow Cover and the Southern Oscillation}

\author{
Randall S. Cerveny, ${ }^{*}$ Brent R. SKeeter and KenNeth F. Dewey \\ Climatology Program, Department of Geography, University of Nebraska, Lincoln, Nebraska 68588
}

5 May 1986 and 28 August 1986

ABSTRACT

\begin{abstract}
A ten-year (1974-83) satellite record of snow cover is compared to a standard index of the Southern Oscillation. South American snow cover area during the May-October snow season is found to be correlated significantly with the winter SOI values of the same year. The relationship is inverse; periods of low SOI values are associated with extensive South American snow cover while periods of high SOI values occur during years of diminished snow cover. The movements of the Pacific anticyclone and the midlatitude westerlies and subsequent changes in precipitation and temperature patterns are discussed in an analysis of this relationship.
\end{abstract}

\section{Introduction}

Although our understanding of the Southern Oscillation has greatly increased in the wake of recent major climatic episodes, there remain many regions of the earth where its potential influence is not well known. This is primarily a result of the inability to record fluctuations of major climatic variables in these sparsely populated regions. Many areas of the Southern Hemisphere have not been adequately utilized in the global examination of the teleconnections involved with the Southern Oscillation because of the spatial and temporal limitations of current datasets. This problem is being addressed, to some extent, through the use of satellite imagery. For example, Antarctic sea ice information compiled from ten years of NOAA satellite data has shown significant correlations with an index of the Southern Oscillation (Chiu, 1983). Satellite mosaic sequences have been used to demonstrate the increase in South American cyclonic activity during the ENSO event of 1972-73 (Streten, 1975).

Past analyses over the land area of South America have been limited to surface measurements of climatic variables such as rainfall. Quinn and Neal (1983) have suggested a relationship between ENSO events and abnormally heavy rainfall in Santiago and Valparaiso, Chile. Because of the sparsity of other rainfall datasets, this type of research has not been extended to other areas of South America.

Analysis of satellite data provides a new and spatially continuous means of examining the relationship between precipitation and the Southern Oscillation. A digital archive of the annual variations in the spatial extent of the snow cover over South America (Dewey

\footnotetext{
- Current affiliation: Department of Geography, Arizona State University, Tempe, AZ 85287.
}

and Heim, 1983) is now available for the period 197483. The purpose of this study is to use that dataset in a preliminary evaluation of the relationship between South American snow cover and the Southern Oscillation.

\section{Data}

The only continuous imagery available of Southern Hemisphere snow cover is that provided by the Defense Military Satellite Program (DMSP). These imagery were analyzed to produce a digitized archive of weekly snow cover for the period 1974 through 1983. The snow cover was digitized on an $89 \times 89$ grid, identical to one used to archive Northern Hemisphere snow cover (Dewey and Heim, 1982). The snow cover of Australia, New Zealand and Africa either occurred too infrequently or did not cover a sufficient enough area to be digitized on this grid. Therefore, only South American snow cover was used in this analysis. Snowfall over the highlands of southeast Brazil was generally of shortterm duration, lasting only a maximum of three days. Summer snow cover was limited to the alpine areas of South America and comprised an area too small to be mapped on this $89 \times 89$ grid. Therefore, only the winter months, May through October, were used to define the annual snow season of South America. In general, extensive South American snow and ice fields did not extend equatorward of $20^{\circ} \mathrm{S}$. Winter snowfall was primarily limited to the mountainous region of South America.

\section{Analysis and discussion}

Weekly values of snow cover during May through October were averaged to produce the snow cover mean for each of the ten years of record. The wide range in mean annual snow cover area extending from 3.60 
TABLE 1. Correlation coefficients (with significance levels in percentages) between monthly values of the Southern Oscillation Index and the average May-October snow cover over South America for the period 1974-83.

\begin{tabular}{lllllllllllll}
\hline & Jan & Feb & Mar & Apr & May & Jun & Jul & Aug & Sep & Oct & Nov & Dec \\
\hline Snow cover & 0.044 & -0.033 & 0.179 & -0.145 & -0.329 & -0.636 & -0.636 & -0.411 & -0.476 & -0.297 & -0.232 & -0.439 \\
Significance & 45 & 46 & 31 & 34 & 17 & 2 & 2 & 11 & 8 & 20 & 25 & 10 \\
\hline
\end{tabular}

$\times 10^{5}$ square kilometers $(1981)$ to $4.79 \times 10^{5}$ square kilometers (1976) demonstrates the high variability of South American snow cover. Average May-October values of the South American snow cover area were correlated with monthly values of a standard Southern Oscillation Index (SOI), the Tahiti-Darwin surface pressure difference (Chen, 1982; Parker, 1983). Simple correlation coefficients $(r)$ for the relationship show that the strongest associations exist between South American snow cover and the June and July values of the SOI (Table 1). The correlation coefficients for both June and July SOI values and the May-October average of the South American snow cover were on the order of -0.63 . In other words, over $40 \%$ of the variance in the South American snow cover is accounted for by the fluctuations in these SOI values. These correlations are significant at the $97.5 \%$ confidence level. The strongly negative correlation also demonstrates the inverse direction of the relationship between winter SOI values and snow cover.

Because of the high variability inherent in monthly SOI values, a better measure of the strength of the relationship between the SOI and South American snow cover may be obtained by time smoothing the SOI values. Calculation of seasonal SOI values is one means of smoothing the monthly fluctuations. Simple correlation coefficients for the relationship between seasonal SOI values and snow cover confirm the monthly findings that a third or more of the variance in snow cover during May-October is accounted for by fluctuations in the winter (June-August) SOI values (Table 2). These correlations also show the strong seasonality of the SOI values. The strong winter association is countered by the statistically insignificant correlations between May-October snow cover and the remaining three seasons.

Additional evidence of an inverse association between the winter SOI values and Southern Hemispheric snow cover is seen in a graph of standardized values

TABLE 2. Correlation coefficients (with significance levels in percentages) between seasonal values of the Southern Oscillation Index and the average May-October snow cover over South America for the period 1974-1983.

\begin{tabular}{lcccc}
\hline & $\begin{array}{c}\text { Summer } \\
\text { (Dec-Feb) }\end{array}$ & $\begin{array}{c}\text { Fall } \\
\text { (Mar-May) }\end{array}$ & $\begin{array}{c}\text { Winter } \\
\text { (Jun-Aug) }\end{array}$ & $\begin{array}{c}\text { Spring } \\
\text { (Sep-Nov) }\end{array}$ \\
\hline Snow cover & 0.0024 & 0.0262 & -0.5720 & -0.3725 \\
Significance & 49 & 47 & 4 & 15 \\
\hline
\end{tabular}

of each variable (Fig. 1). Low SOI values for winters of 1977 and 1982 occurred during periods of above normal snow cover. Similarly, the above normal SOI values in the winters of 1975,1979 and 1981 corresponded to periods of greater than average snow cover in South America. The stronger response of snow cover to high SOI values during winter gives support to van Loon and Shea's (1985) hypothesis that cold events (defined as extremes of the Southern Oscillation when pressures are abnormally low over the western South Pacific and abnormally high over the eastern South Pacific) may be as important as ENSO events in terms of their associated midlatitude teleconnections.

The dramatic changes in the extent of South American snow cover under the influence of the two extremes in the Southern Oscillation are apparent in maps

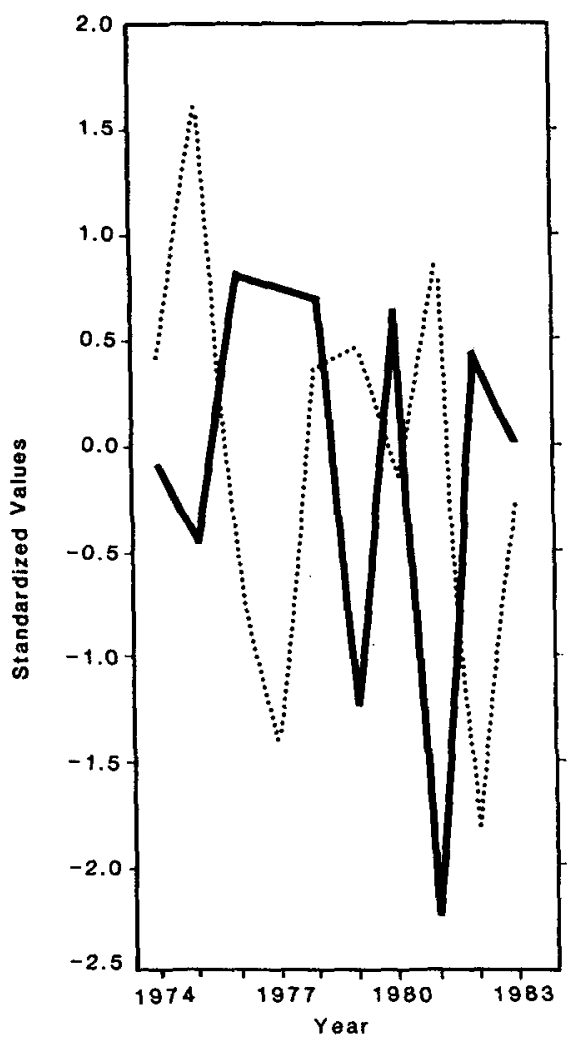

FIG. 1. Time series of the standardized values of the average Southern Hemisphere winter (June-August) SOI (dotted line) and the average May-October South American snow cover (solid line) for the period 1974-83 in units of standard deviations. 
showing the average May-October coverage of snow for 1981, a period of high winter SOI values, and for 1982, which included a winter that was characterized by low SOI values (Figs. 2 and 3). Average May-October snow cover area is computed using those grid boxes that were at least $50 \%$ covered by snow for one half or more of the snow cover season. The period of high SOI values during the winter of 1981 shows a very limited continuous snow cover confined to an area south of $45^{\circ} \mathrm{S}$ that represents only the tip of South America. In contrast, the low SOI values of 1982 are associated with a much more extensive snow cover which stretches from the tip of South America equatorward as far north as $31^{\circ} \mathrm{S}$.

Although this preliminary analysis suggests the potential existence of a strong statistical relationship between the May-October South American snow cover and the Southern Oscillation, the physical mechanisms associated with this relationship are undoubtedly complex. Streten's (1975) analysis of satellite imagery of cyclonic storms over the Southern Hemisphere indicates that cyclonic frequency is more pronounced between $20^{\circ}$ and $40^{\circ} \mathrm{S}$, rather than farther south during ENSO events such as that of 1972 . As demonstrated in Fig. 3, the increased winter snow cover apparent during the low SOI values of the winter of 1982 is primarily the result of snow cover north of $45^{\circ}$. Past studies have suggested that the abnormally heavy rainfall found in the Chilean lowlands during ENSO events is associated with the Southern Hemisphere winter circulation and not the summer movement of the Intertropical Convergence Zone (Caviedes, 1975). In winter, the southeast Pacific subtropical high weakens and the midlatitude westerly flow with accompanying cyclones penetrates farther northward. It is apparent that such a movement of the westerlies in winter would also likely result in increased snow cover.

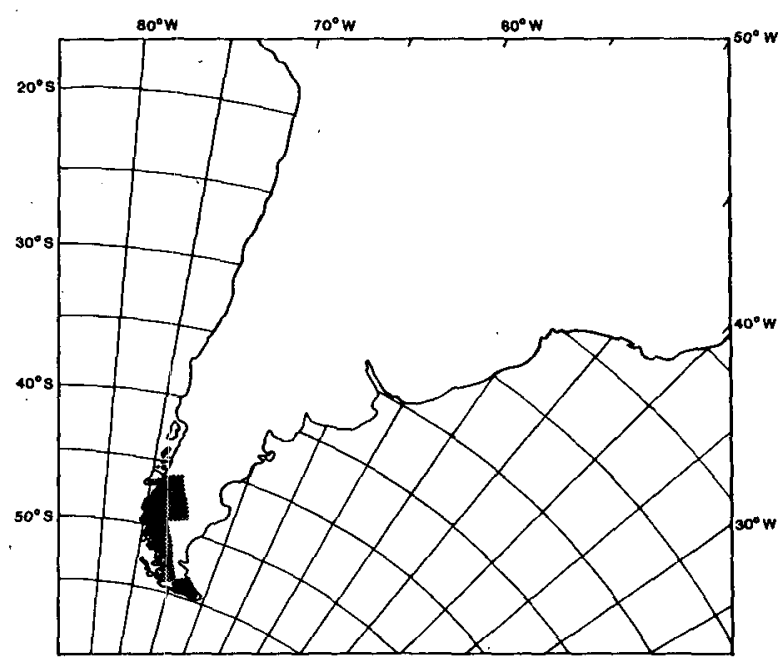

FIG. 2. The average ( $50 \%$ frequency) snow cover over South America during the year of 1981 (a period of high winter SOI values).

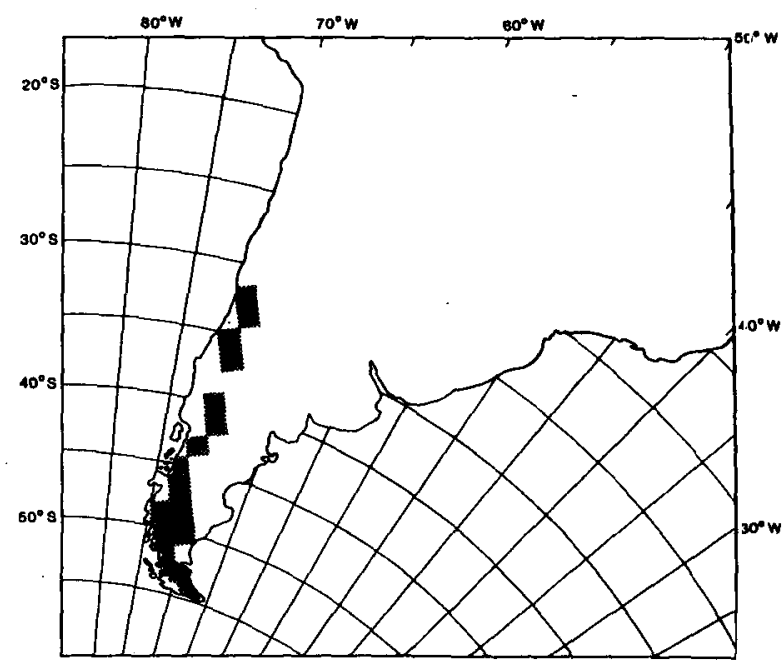

FIG. 3. The average ( $50 \%$ frequency) snow cover over South America during the year of 1982 (a period of low winter SOI values).

Snow cover is primarily a function of two varialoles, atmospheric moisture and temperature. Moisture determines the amount of snow falling over a given area, while temperature influences the extent and persistence of the snow resulting from that precipitation. An equatorward movement of the Southern Hemispheric vesterlies during the winters experiencing low SOI values would result in a greater precipitation rate between. $20^{\circ}$ and $40^{\circ} \mathrm{S}$, due to increased cyclonic passage. More frequent cyclonic activity would also likely result in increased cloud cover, and thus would tend to produce cooler temperatures in those areas away from the immediate influence of the warmer ocean waters. This would mean that the cooler areas would primarily be limited to the inland mountainous areas. These two effects, cooler temperatures and increased precipitation, combine to produce an expanded area of snow cover over South America, particularly in the mountainous areas.

Conversely, during winters of high SOI values, the alpine regions of western South America experience warmer and drier conditions. The winter circulation is predominately influenced by the strengthening of the southeast Pacific subtropical high (Quinn, 1974) and northeast airflow over the region between $20^{\circ}$ and $40^{\circ} \mathrm{S}$. This circulation would tend to inhibit precipitation and promote the advection of warmer air into the mountainous region of South America. This would result in a reduction in the areal coverage of snow in South America.

The maps showing the snow cover produced cluring above and below normal fluctuations of the Sovthern Oscillation (Figs. 2 and 3) also demonstrate the latitudinal limits of the influence of these fluctuations. The snow area south of $45^{\circ} \mathrm{S}$ is visible during, both types of pressure variations associated with the Southern Oscillation and therefore is consistently under the 
influence of the midlatitude westerlies and colder polar temperatures. The influence of the Southern Oscillation on snow cover in South America appears to be limited to the region north of $45^{\circ} \mathrm{S}$.

There is evidence, however, that the strength and direction of this relationship may vary with latitude. Ice core data (Thompson et al., 1984) for the period 1965-83 from the tropical Quelccaya Ice Cap, Peru $\left(13^{\circ} 56^{\prime} \mathrm{S}, 70^{\circ} 50^{\prime} \mathrm{W}\right)$ revealed a substantial decrease in snow accumulation in association with the last five ENSO events. The Quelccaya precipitation, in contrast to the area south of $20^{\circ} \mathrm{S}$, primarily originates from the Amazon Basin to the east. This study suggests that the increased snow cover between $20^{\circ}$ and $40^{\circ}$ is primarily influenced by a weakening of the subtropical Pacific high and an expansion of the midlatitude westerlies into the region. Such an expansion would undoubtedly result in changes in the circulation of the tropics to the north and may lead to decreases rather than to increases in tropical snow accumulation.

\section{Conclusions}

This preliminary study provides the first application of satellite snow cover imagery to the investigation of the Southern Oscillation. It suggests the existence of a strong inverse relationship between South American snow cover and a standard Southern Oscillation Index. The strength of this relationship is particularly interesting, given the dependence of snow cover on two distinct climatic variables, temperature and atmospheric moisture. While the limited sample size of the satellite database does not permit a complete assessment of a snow cover-Southern Oscillation relationship, this preliminary research does develop a foundation for further analysis. A longer Southern Hemispheric satellite record would obviously permit a more detailed investigation. The corresponding Northern Hemispheric snow cover database (Dewey and Heim, 1981), with records back to 1966 , has been employed in a variety of comparative studies (e.g., Walsh et al., 1982, Heim and Dewey, 1984; Namias, 1985; Walsh et al., 1985). Extension of the Southern Hemispheric snow cover archive back to 1966 , together with analysis of recent snowfall events, could increase the database to 20 years and allow inclusion of the major 1972-73 El Niño event.

Climate modeling studies have indicated that snow cover has a potentially large impact on climate through albedo-temperature feedback mechanisms (North et al., 1981). The Southern Oscillation, particularly as evi- denced in ENSO events, has had a dramatic impact on the global climate. The existence of a relationship between South American snow cover and the Southern Oscillation may prove beneficial in our understanding of the spatial and temporal mechanisms of the climatic system.

Acknowledgments. We are sincerely grateful for the valuable comments and suggestions of Dr. Richard Rosen and two reviewers.

\section{REFERENCES}

Caviedes, C. N., 1975: El Niño 1972: Its climatic, ecological, human and economic implications. Geogr. Rev., 65, 493-509.

Chen, W. Y., 1982: Assessment of Southern Oscillation sea level pressure indices. Mon. Wea. Rev., 110, 800-807.

Chiu, L. S., 1983: Antarctic sea ice variations 1973-1980. Variations in the Global Water Budget, A. Street-Perrott, M. Beran, and R. Ratcliffe, Eds., D. Reidel, 301-311.

Dewey, K. F., and R. Heim, 1981: Satellite observations of variations in Northern Hemisphere snow cover. NOAA Tech. Rep. NESS 87. U.S. Govt. Printing Office, 20402; 83 pp.

$\longrightarrow$, and - 1982: A digital archive of Northern Hemisphere snow cover, November 1966 through December 1980. Bull. Amer. Meteor. Soc., 63, 1132-1141.

- , and - 1983: Satellite observations of variations in Southern Hemisphere snow cover. NOAA Tech. Rep. NESDIS 1, National Technical Information Service, 20235; 20 pp.

Heim, R., and K. F. Dewey, 1984: Circulation patterns and temperature fields associated with extensive snow cover on the North American continent. Phys. Geogr., 5, 66-85.

Namias, J., 1985: Some empirical evidence for the influence of snow cover on temperature and precipitation. Mon. Wea. Rev., 113, 1542-1553.

North, G. R., R. F. Cahalan and J. A. Coakley, 1981: Energy balance climate models. Rev. Geophys. Space Phys., 19, 91-121.

Parker, D. E., 1983: Documentation of a Southern Oscillation index. Meteor. Mag., 112, 184-188.

Quinn, W. H., 1974: Monitoring and predicting El Niño invasions. J. Appl. Meteor., 13, 825-830.

-, and V. T. Neal, 1983: Long-term variations in the Southern Oscillation, El Niño, and Chilean subtropical rainfall. Fishery Bull., 81, 363-374.

Streten, N. S., 1975: Satellite derived inferences to some characteristics of the South Pacific atmospheric circulation associated with the Niño event of 1972-73. Mon. Wea. Rev., 103, 989-995.

Thompson, L. G., E. Mosley-Thompson and B. Arnao, 1984: El Niño-Southern Oscillation events recorded in the stratigraphy of the tropical Quelccaya Ice Cap, Peru. Science, 226, 50-53.

van Loon, H., and D. J. Shea, 1985: The Southern Oscillation. Part IV: the precursors south of $15^{\circ} \mathrm{S}$ to the extremes of the oscillation. Mon. Wea. Rev., 113, 2063-2074.

Walsh, J. E., D. R. Tucek and M. Peterson, 1982: Seasonal snow cover and short term climate fluctuations over the United States. Mon. Wea. Rev., 110, 1474-1485.

- W. H. Jasperson and B. Ross, 1985: Influence of snow cover and soil moisture on monthly air temperature. Mon. Wea. Rev., $113,756-768$. 